University of Nebraska - Lincoln

DigitalCommons@University of Nebraska - Lincoln

Faculty Publications: Department of Entomology

Entomology, Department of

4-1968

Seasonal Lipid Content of Bagworm Larvae

E. A. Heinrichs

Follow this and additional works at: https://digitalcommons.unl.edu/entomologyfacpub

Part of the Entomology Commons, Forest Sciences Commons, and the Horticulture Commons

This Article is brought to you for free and open access by the Entomology, Department of at

DigitalCommons@University of Nebraska - Lincoln. It has been accepted for inclusion in Faculty Publications:

Department of Entomology by an authorized administrator of DigitalCommons@University of Nebraska - Lincoln. 
Published in Journal of Economic Entomology 61:2 (April 1968), p. 585; doi: 10.1093/jee/61.2.585

Copyright $\odot 1968$ Entomological Society of America; published by Oxford University Press. Used by permission.

Accepted December 21, 1967; published April 1, 1968.

\title{
Seasonal Lipid Content of Bagworm Larvae ${ }^{1,2}$
}

\author{
E. A. Heinrichs ${ }^{3}$
}

Department of Agricultural Biology, University of Tennessee Agricultural Experimental Station, Knoxville, Tennessee, USA

It is common knowledge to many who have attempted to control bagworms Thyridopteryx sp., that early instars are fairly easy to control, while later larval stages are less susceptible to insecticides. Studies of other insects (Bennett and Thomas 1963, Munson and Gottlieb 1953, Munson et al. 1954, Reier et al. 1953) have shown that as the lipid content increases, the susceptibility to insecticides (especially chlorinated hydrocarbons) decreases. To determine whether the lipid content of the bagworm larva increased with age a series of lipid extractions was conducted.

\section{Methods and Materials}

Larvae were collected from white pine, Pinus strobus L., on the University of Tennessee campus beginning July 5, 1967, when most of the larvae were in an early instar. Collections were terminated September 13, 1967, when many of the larvae had already pupated.

Lipid content was expressed as the total of ether-extractable material expressed as percentage of dry weight of the larva. From 4 to 20 larvae (sexes were not determined) were used for each lipid determination. Larvae were killed and weighed, then dried in an oven at $70^{\circ} \mathrm{C}$ for $24 \mathrm{hr}$ and weighed again. Lipid was then extracted with ethyl ether in a Soxhlet extractor for $10 \mathrm{hr}$. After extraction, larvae were oven dried and weighed and percent lipid was calculated. 


\section{Results and Discussion}

Lipid content was lowest on July 5 (Table 1). Lipid content increased only slightly from July 5 to July 27. However, it more than doubled (3.20-7.02\%) in the month of August. Peak lipid content was reached September 13, just prior to pupation.

Table 1. Lipid and moisture content of bagworm larvae on various dates

\begin{tabular}{|c|c|c|c|}
\hline \multirow[b]{2}{*}{ Date lipid extracted } & \multirow[b]{2}{*}{ No. larvae } & \multicolumn{2}{|c|}{ Percent } \\
\hline & & Lipida $^{a}$ & Moisture \\
\hline July 5 & 10 & 1.32 & 82.02 \\
\hline 12 & 20 & 1.45 & 83.37 \\
\hline 19 & 15 & 1.45 & 83.18 \\
\hline 27 & 10 & 1.51 & 83.26 \\
\hline August 2 & 15 & 3.20 & 80.17 \\
\hline 8 & 15 & 4.90 & 77.54 \\
\hline 16 & 16 & 5.28 & 77.22 \\
\hline 23 & 15 & 6.15 & 76.81 \\
\hline 30 & 15 & 7.02 & 74.12 \\
\hline September 13 & 4 & 9.55 & 73.81 \\
\hline
\end{tabular}

a. Percentage of dry weight of larvae

The effect of lipid content on susceptibility of bagworm larvae to insecticides was not determined. However, if greater lipid content results in increased resistance to insecticides, the $\mathrm{LD}_{50}$ would be expected to be much greater in September than in July.

\section{Notes}

1. Lepidoptera: Psychidae

2. Accepted for publication December 21, 1967

3. Assistant professor

\section{References Cited}

Bennett, S. E., and C. A. Thomas, Jr. 1963. The correlation between lipid content and percent mortality of the alfalfa weevil to heptachlor and malathion. J. Econ. Entomol. 56(2): 239-40.

Munson, S. C., and M. I. Gottlieb. 1953. The differences between male and female American roaches in total lipid content and in susceptibility to DDT. J. Econ. Entomol. 46(5): 798-802.

Munson, S. C., G. M. Padilla, and M. L. Weissmann. 1954. Insect lipids and insecticidal action. J. Econ. Entomol. 47(4): 578-87.

Reiser, R. D., C. Chadbourne, K. A. Kuiken, C. F. Rainwater, and E. E. Ivy. 1953. Variations in lipid content of the boll weevil and seasonal variation in its resistance to insecticides. J. Econ. Entomol. 46(2): 337-40. 